\title{
Watershed Plan Implementation Challenges for SMS4s in Murrells Inlet
}

\author{
Dave Fuss ${ }^{1}$, Dan Newquist ${ }^{2}$, Sue Sledz ${ }^{3}$, Tracy Jones ${ }^{4}$, and Daniel R. Hitchcock ${ }^{5}$
}

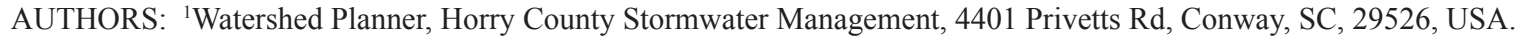
${ }^{2}$ Regional Planner, Waccamaw Regional Council of Governments, 1230 Highmarket Street, Georgetown, SC, 29440 , USA. ${ }^{3}$ Former Executive Director, Murrells Inlet 2020, P.O. Box 1357, Murrells Inlet, SC, 29576, USA. ${ }^{4}$ Stormwater Manager, Georgetown County Stormwater Management, 129 Screven Street, Georgetown, SC, 29440, USA. ${ }^{5}$ Associate Professor, Baruch Institute of Coastal Ecology and Forest Science, Clemson University, 130 Heriot Rd, Georgetown, SC, 29440, USA.
\end{abstract}

\begin{abstract}
This case study describes the plan development process, implementation strategies and initial and future challenges to implementation for the Murrells Inlet Watershed Plan (WRCOG, 2014). The Plan was crafted by a group of key stakeholders with community support and guidance to address fecal coliform bacteria loading in shellfish harvesting waters in the Murrells Inlet Estuary along the northeastern South Carolina coast. Stakeholders debated the interpretation of the data analysis and ultimately concluded that the primary pollutant sources were non-human, namely wildlife and domestic animals. Stakeholders also concluded that the loads from these sources were being delivered to the estuary via a landscape that includes a network of surface drainage ditches and subsurface pipes so that water retention on the landscape has been largely short-circuited.

Armed with this information, plan participants devised management measures that encompass several strategies, including: (1) utilize an end-of-pipe/ditch solution that addresses pollution nearest the discharge point; (2) generally reduce volume and flow and/or increase retention/detention across the landscape to reduce the pollutant load; and (3) use education and outreach to achieve behavior change.

During both plan development and the implementation of management measures, the plan steering committee faced significant challenges. Initial challenges include: geographic and space limitations that make the use of large retention or detention devices impractical; lack of state or local requirements to use low impact development techniques to increase retention; and mounting outreach campaigns that cannot guarantee significant pollution reductions. Additional complications include mechanisms to sustain community support and involvement. As implementation progresses, the steering committee must track plan implementation and determine creative ways to evaluate the effectiveness of management measures. Local funding allocations must also be sought to leverage against potential grant funds to enable implementation.
\end{abstract}

\section{INTRODUCTION}

Watershed planning has become increasingly emphasized in a variety of disciplines, including stormwater management, resource conservation and stewardship, and water resource management. Granting and resource management agencies have widely adopted the watershed approach and have published guidelines and manuals to assist communities with watershed planning efforts.

For example, South Carolina Department of Health and Environmental Control (SC DHEC) has embraced the watershed planning concept by encouraging stakeholders in watersheds throughout the state to undertake the watershed planning process. This emphasis manifests itself in the publication of the South Carolina Simplified Guide to Developing Watershed-based Plans (SC DHEC, 2014b) and the offering of a designated Request for Proposals for watershed-based plan development within its Section 319 Grant Program. SC DHEC draws its Simplified Guide from the U.S. Environmental Protection Agency's Handbook for Developing Watershed Plans to Protect and Restore Our Waters (US EPA, 2008).

These helpful documents, which provide needed structure and organization to the watershed planning process (Figure 1), belie the difficulties and challenges of explaining and managing water resources in the face of competing interests within human society. Furthermore, plan development is only part of the process. Implementation of watershed plans poses significant challenges to those tasked with carrying out plan recommendations and management measures. In urbanized areas, that responsibility falls to Small Municipal Separate Storm Sewer Systems (SMS4) such as Georgetown and Horry Counties.

In presenting this case study, we describe the plan development process, implementation strategies and initial and future challenges to implementation for the Murrells Inlet Watershed Plan (WRCOG, 2014). The strategies are intended to achieve reductions in the pollutant load of fecal coliform bacteria to shellfish harvesting waters. 


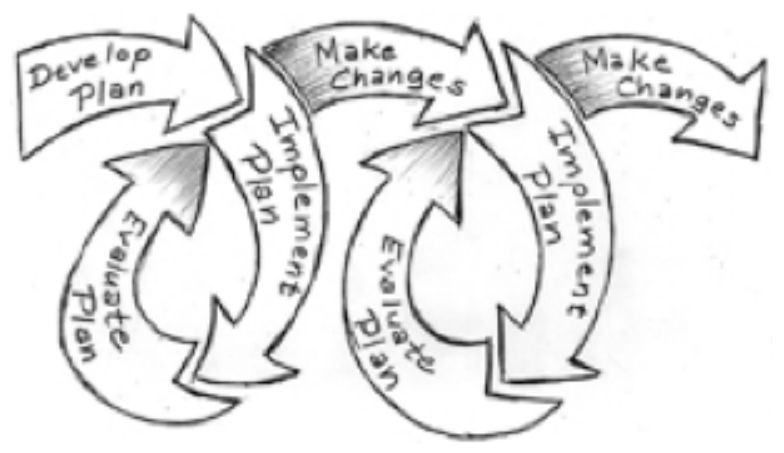

Figure 1. Watershed planning process (US EPA, 2008).

\section{BACKGROUND}

The Murrells Inlet Watershed Plan (WRCOG, 2014) was crafted by a group of key stakeholders with community support and guidance. Murrells Inlet is a coastal community that strongly identifies with its salt marsh and its natural resources, particularly its finfish and shellfish fisheries as signified by the community's nickname of "Seafood Capital of South Carolina." The Murrells Inlet watershed encompasses 9,313 acres in Georgetown and Horry Counties (Figure 2) along part of South Carolina's northeastern coast, which is known as the Grand Strand. The South Carolina Department of Health and Environmental Control (SC DHEC)estimates that the watershed contains 3,108 acres of habitat suitable for shellfish production. As of 2012, 2,217 acres (71\%) of shellfish habitat was approved for shellfish harvesting based on water quality testing at 25 locations throughout the watershed (SC DHEC, 2014a).

Murrells Inlet is the most significant shellfish harvesting area in northeastern South Carolina, and it boasts a robust commercial fishing industry. In addition, the seafood restaurants that line the Murrells Inlet Marshwalk, (spearheaded by the community preservation organization Murrells Inlet 2020) and the many recreational fishermen and nature lovers who use the Marshwalk for access to the marsh serve as symbols that the economic and cultural underpinnings of the community are inextricably linked to the salt marsh and its resources.

Yet, the salt marsh is exposed to fecal coliform bacteria that has resulted in some oyster beds being closed to harvesting for violations of water quality standards that are designed to protect the safe consumption of raw shellfish. Some SC DHEC water quality monitoring stations in Murrells Inlet Estuary were listed on the state's 303(d) impaired waters list. As a result, SC DHEC issued a Total Maximum Daily Load report (TMDL) in 2005 that included pollutant load reductions allocated to SMS4s within the Murrells Inlet Estuary watershed, namely Georgetown and Horry Counties (SC DHEC, 2005).

The 303(d) list and the TMDL are both elements of the federal Clean Water Act that are designed to protect and restore water bodies with impairments linked to specific pollutants. The TMDL for Murrells Inlet Estuary generally

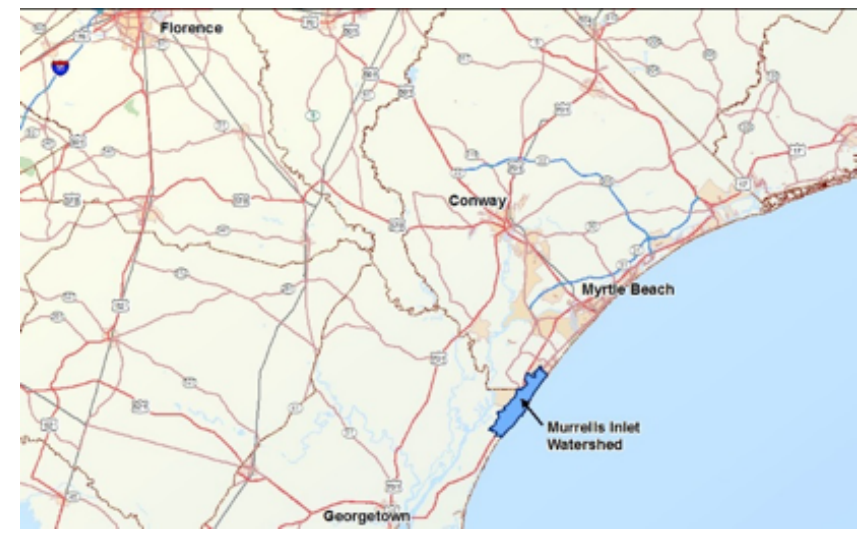

Figure 2. Murrells Inlet Watershed is located between Myrtle Beach and Georgetown along South Carolina's northeastern coast (map by Stephen Williams, The Earthworks Group).

identifies non-point sources as the main contributor of pollutants, but identifies neither specific pollutant sources nor strategies for mitigating pollutant loads. Those tasks are left to the local communities and require considerable effort, expertise, and financial support.

The State of South Carolina National Pollutant Discharge Elimination System General Permit for Stormwater Discharges from Regulated SMS4s that became effective January 1, 2014 now requires SMS4s to implement monitoring and management measures to address impairments for waters with approved TMDL reports and for those listed on the 303(d) impaired waters list. In an effort to address these impairments prior to the issuance of the new SMS4 permit, the Murrells Inlet community engaged in cross-jurisdictional watershed planning in 2012 with grant funding from the SC DHEC 319 Grant Program for Watershed-Based Plan Development.

The stakeholder-based planning process was led by the Waccamaw Regional Council of Governments and Murrells Inlet 2020, a community cultural and environmental preservation group. The project cooperators engaged as many community members as possible in order to gain a thorough understanding of the social, environmental and economic issues and the various perspectives and viewpoints that were represented in the community at large. Stakeholder activities and meetings attracted realtors, business owners, community activists, water quality monitoring volunteers, state park rangers, and seafood industry representatives. The involvement of a wide range of community members yielded valuable information about both the estuary and the community. Meanwhile, this stakeholder engagement also raised community expectations for on-the-ground environmental improvement to flow from the final watershed plan recommendations.

The effort lasted one and a half years and involved considerable debate and data analysis. Initially, an inperson and online mapping effort engaged stakeholders by asking them to identify possible pollutant sources based on their observations and knowledge of the watershed 
landscape. While involving stakeholders is time-consuming, it is important to offer opportunities for participation in the process in order to gather expert and local knowledge and achieve an enhanced understanding of the issues and increased likelihood of consensus (Treby and Clark, 2004). These stakeholder observations were paired with detailed expert analysis of decades of water quality data and rainfall information in order to inform interpretations of analysis results and to discern correlations that might invite more thorough field investigation. This step led to additional field reconnaissance, which ultimately helped to inform the prioritization of locations for management measures that address pollutant sources.

While at times the planning process was confusing and contentious, stakeholders energetically debated the interpretation of the data analysis and field observations, and ultimately concluded that the primary pollutant sources were non-human, namely wildlife and domestic animals. Stakeholders also concluded that the loads from these sources were delivered to the estuary via a landscape that is characterized by a dense network of surface drainage ditches and subsurface pipes so that retention of storm runoff on the landscape has been largely short-circuited. Following more comprehensive and detailed investigation, human sources were eliminated as a significant contributor, with the exception of rare accidental discharges.

\section{PROJECT CHALLENGES}

During both plan development and the implementation of management measures, the plan steering committee faced significant challenges. Starting with the conclusions of the analysis of data and field investigations, project cooperators were confronted with the difficult task of devising Best Management Practices (BMP) that address both the major pollutant sources and the aggressive pollution reduction estimates established in the TMDL. Given that pollution sources in Murrells Inlet are widespread and are primarily delivered to the impaired receiving waters via a highly modified, dense drainage network that accompanies development, increasing retention on the landscape using either conventional BMP such as wet detention ponds or low impact development (LID) devices such as bioretention areas is appropriate. With a fairly high density of land use already on the landscape, however, geographic limitations make the extensive use of such devices impractical. Not enough space is available to accommodate the number of large detention/ retention devices needed.

Furthermore, pollutant mitigation devices that target bacteria have been designed for use in specific geographic locations within small drainage areas with relatively low flows, such as catch basins and curb inlets. Extensive treatment with such devices was deemed impractical, expensive and unlikely to target all or even many of the pollutant contributors. Wildlife and domestic pets such as dogs are typically attracted to vegetated drainage ditches along the roadside or between lots. Anecdotal evidence suggests that the higher-flow pathways like large, vegetated outfall ditches actually serve to concentrate wildlife, so an attempt to treat any of these sources by using devices in upstream catch basins would fail to intercept the primary pollutant sources.

Pollution reduction estimates in the TMDL are significant, approximately $80 \%$. With the constraints on the use of large BMP, it became clear that it would be difficult to sufficiently address the pollution reductions in the TMDL. A challenge for project cooperators was to identify innovative, specialized devices manufactured to target bacteria as a pollutant in stormwater runoff (i.e. nonpoint sources) and apply them within the landscape's limitations, which likely include untested settings for the devices.

Low impact development devices are known to increase retention on the landscape. Collectively across the landscape, the use of small devices such as rain barrels and rain gardens on individual lots can amount to significant reduction in the volume of stormwater runoff. The challenge for implementing LID on a scale large enough to address the TMDL reduction requirements is that there are currently no state or local requirements for the widespread use of LID in new or existing development. While there is a guidance manual for using LID in coastal South Carolina (Ellis et al, 2014), the document has not been adopted by the South Carolina Department of Health and Environmental Control. There are also no specific state requirements for the use of LID. Likewise, at the local level in Horry and Georgetown Counties, instituting requirements to widely use LID in new developments has not been politically feasible.

The use of education and outreach campaigns to spread a watershed plan's messages and change behaviors to address pollution reduction is typically a part of a watershed plan's recommendations. By their voluntary nature, however, such campaigns do not guarantee compliance with the management measures and therefore may not translate into significant pollution reductions that meet the TMDL requirements. Designing and supporting such campaigns so that they will be effective will be a challenge. Furthermore, in general, sustaining community involvement and identifying designated funding mechanisms to implement the plan's recommendations pose long-term challenges for the plan's steering committee.

\section{INITIAL STRATEGIES}

In the face of these challenges and the conclusions from the data analysis, project cooperators chose to consider the following strategies: (1) utilize an end-of-pipe/ditch solution that addresses pollution nearest the discharge point to the estuary; (2) generally reduce volume and flow and/or increase retention/detention across the landscape to reduce delivery of the pollutant load; and (3) utilize education, outreach, and incentive programs to achieve behavior change. 


\section{Discharge Point Strategies}

The first of the project strategies requires either radical modification (e.g. retrofitting) of the existing drainage system or application of manufactured BMP technology in untested, high-flow settings for which the technology was not originally designed. Retrofitting the drainage system is hampered by space limitations around existing buildings and structures, while the feasibility of untested technology across the landscape warrants pilot studies to prove efficacy.

Based on available research of existing bacteria removal methods, the project cooperators determined that the ideal strategy for bacteria removal is to maximize runoff retention time on the landscape by incorporating detention basins, particularly those with vegetation, into the current drainage system. Increasing retention time lengthens exposure to natural causes of bacteria mortality, such as sunlight and predators. The project cooperators chose to adapt the concept of deploying wetland systems for treating pollutants in wastewater (Iasur-Kruh et al, 2010; Karathanasis et al, 2003) to a setting for treating stormwater with shoreline vegetation or floating treatment wetlands in detention basins.

In the Horry County portion of Murrells Inlet, however, the drainage is handled primarily along the roadside ditch network which cannot physically accommodate detention basins due to space constraints and road construction standards. In Georgetown County, the drainage network primarily concentrates higher flows into larger canal-style ditches that pass between lots, many of which are already developed. With these geographic constraints, limited opportunities exist to incorporate detention basins into the landscape. One location in Georgetown County lends itself to the creation of constructed stormwater wetlands to serve as a detention basin. This project was identified as a priority in the watershed plan. Besides this location, however, the current landscape conditions limit retention options. This reality pushed the stakeholders towards the concept of utilizing technology in higher-flow conditions, although the technology was originally designed for and has only been tested in low-flow conditions.

Bacteria media filter socks have been deployed in roadside drainage ditches in Horry County (Figure 3 ) and are planned for deployment in canal-style drainage ditches between lots in Georgetown County. One challenge in Georgetown County is to acquire the easements needed to deploy the filter socks. Bacteria media filter socks have been shown to be effective in pollutant removal in controlled settings (Faucette et al, 2013), but have not been tested in ditches. As a pilot project, the filter socks are installed as a series of small check dams within the ditches (Figure 4) in an effort to create a series of micro pools to increase retention time and maximize contact with the media.

In addition, floating treatment wetlands and submerged colloidal filters will be installed in several in-line detention ponds (Figure 5) to intercept and reduce the pollutant loads. Much like constructed stormwater or wastewater treatment wetlands, floating treatment wetlands (Figure 6) have been successfully used to sequester pollutants such as nutrients, heavy metals, and suspended solids (Masters, 2012; Tanner and Headley, 2011). They will be used in Murrells Inlet to help capture sediments to which fecal coliform bacteria attach and move with stormwater runoff. Colloidal filters target sediment particles that transport fecal coliform bacteria. Both the floating islands and colloidal filters have a porous, extruded plastic matrix that maximizes the surface area for periphytic biofilm to form. Sediments to which pollutants adhere will tend to attach to the combination of vegetation and biofilm, which is the basis for pollution reduction (Tanner and Headley, 2011). In addition, by reducing turbidity caused by sediments in the water column, sunlight penetration should increase. Fecal coliform bacteria are susceptible to ultraviolet radiation from sunlight, which is a secondary benefit from this strategy.

\section{Strategies to Increase Retention}

The second strategy utilizes widespread implementation of Low Impact Development (LID) techniques to increase retention across the landscape. LID is designed to mimic natural hydrology by integrating practices across the landscape that reduce runoff close to its source (Ellis et al, 2014). Pollutant loads are reduced by reducing stormwater runoff volume. This strategy includes the use of devices such as bioretention swales, rain gardens or constructed wetlands, as well as rain barrels or cisterns.

Bioretention swales are linear features that use biological processes to sequester pollutants in storm runoff, preventing them from reaching adjacent waterways. Bioretention swales differ from simple vegetated swales in that the native soils are excavated and replaced with an engineered soil mix that is designed to infiltrate storm runoff and bind pollutants to soil particles (Ellis et al, 2014). Plantings in bioretention swales range from turf grass to shrubs and flowers with mulch. Rain gardens are similar to bioretention swales but are typically more compact in shape and more closely resemble landscaped beds. A bioretention swale is planned along an existing drainage ditch adjacent to a water quality monitoring station on the north end of the Murrells Inlet estuary.

Constructed stormwater wetlands are best management practices that use biogeochemical processes found in wetland systems to process pollutants (Ellis et al, 2014). They also increase retention time on the landscape. These devices typically have a range of habitats including permanent pools and wet meadows that are planted with native wetland species (Figure 7). They may be used as an alternative to wet detention ponds. A constructed stormwater wetland basin is planned for a location in Georgetown County on the south end of the Murrells Inlet estuary that is adjacent to an existing volunteer water quality monitoring location. The basin is being designed by faculty and students at Clemson University. This highly visible location is owned by Murrells Inlet 2020, the community preservation organization, and will take advantage of a high water table.

Collectively, rainwater harvesting using rain barrels (Figure 8) or cisterns at homes and businesses can reduce the volume of storm runoff flowing across the landscape (Ellis et 

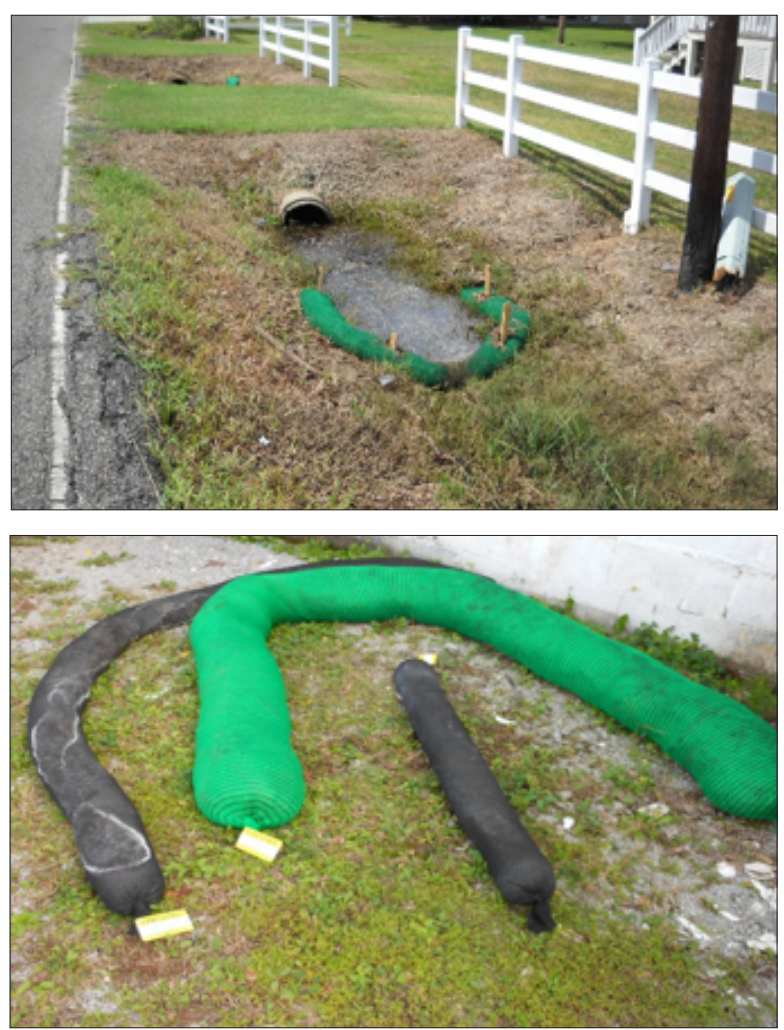

Figure 3. Bacteria media filter socks and an installation site along Vista Drive in Horry County.

al, 2014). Increasing retention on the landscape is an effective way to reduce the pollutant load reaching adjacent waterways. Recent efforts to offer rain barrels at reduced rates, along with easy installation instructions, have been hosted by community organizations. This will continue to be a strategy.

The benefits of LID are best realized when these techniques are used throughout the landscape (Ellis et al, 2014). The lack of specific local or state requirements for using LID poses a complication for the widespread use of LID techniques. Faced with voluntary participation, education and incentives will need to be used cooperatively to establish interest and confidence in this approach among homeowners.

\section{Outreach and Education Campaigns}

The third strategy addresses education, outreach and incentive campaigns to change the behavior of target audiences. One example is a pet waste outreach and cleanup campaign, perhaps in concert with the establishment of pet waste ordinances. Many communities around the country have instituted this approach, including some of those along the Grand Strand. Dog waste has been shown to be a significant contributor in some subwatersheds of Murrells Inlet Estuary (WRCOG, 2014).

The Coastal Waccamaw Stormwater Education Consortium, supported by its member SMS4s, has been developing a pet waste cleanup campaign during the last two years. SMS4s and education partners have installed pet waste cleanup stations in numerous public spaces. This effort has

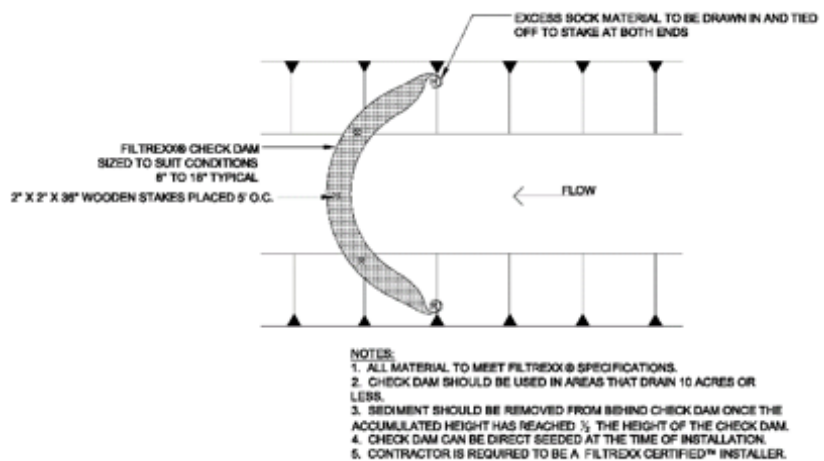

Figure 4. Drawing of bacteria media filter sock used as a check dam in roadside and canal-style ditches (Credit: Filtrexx International).

been complemented by the common use of similar pet waste stations by homeowner associations.

While these stations offer the tools for cleanup, they do not guarantee compliance by pet owners. The intention is to continue to educate the public so that pet waste cleanup becomes the norm, rather than an uncommon occurrence. In addition to the inherent challenge of establishing a new norm, the fact that pet waste is only a partial contributor to the water quality problem means that such a campaign may be difficult to link directly with significant water quality improvements. Even if pet waste is completely eliminated from storm runoff, there remain other sources of fecal coliform bacteria that may cause water quality monitoring stations to remain in violation of water quality standards.
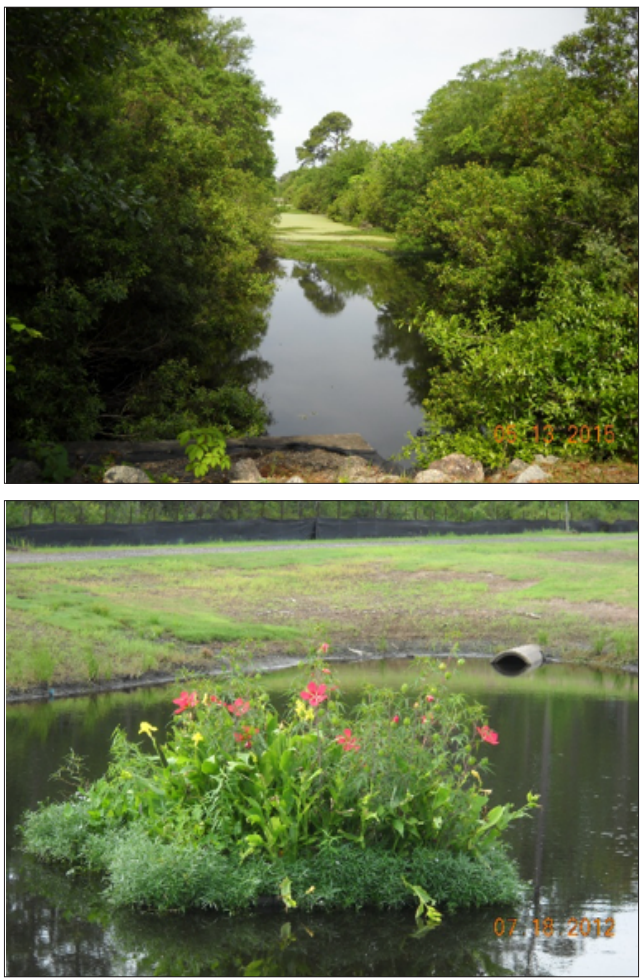

Figure 5. Floating treatment wetlands and target site at in-line detention pond. 


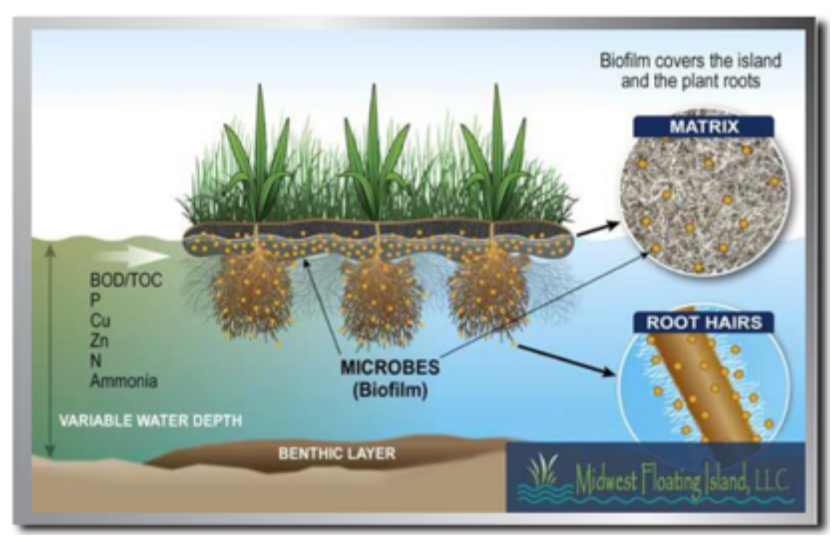

Figure 6. Schematic of floating treatment wetlands, showing floating matrix with biofilm for treatment (Credit: Midwest Floating Island, LLC).

An additional example is the Inlet-friendly Business Program spearheaded by Murrells Inlet 2020. The program targets restaurants and other businesses that operate in Murrells Inlet, particularly those near the Marshwalk, which is a major draw for residents and tourists alike. Started less than a year ago, the program aims to encourage environmentallyfriendly practices by recognizing program participants with window plaques and website acknowledgements. The businesses can use the recognition as a marketing tool to the discerning public that is increasingly seeking to patronize "green" businesses. Activities include committing to manage and maintain dumpster areas; safely disposing of grease and wash water; and avoiding "water brooming" of parking lots and storage or work areas, which are known as a non-point source for fecal coliform bacteria. The challenge for this program is to provide enough incentives to attract businesses' interest in participation. Another challenge will be adapting this program to the residential sector to achieve pollution reductions.

\section{FUTURE CHALLENGES}

As watershed plan implementation moves forward, SMS4s will have to use a strategic approach to determine effectiveness of BMPs in addressing the water quality impairments. Continued financial support and expansion of existing monitoring programs conducted and overseen by Coastal Carolina University's Environmental Quality Laboratory, including volunteer monitoring, will be needed to evaluate the impacts of BMPs. Generally, BMPs are targeted in areas where long-term monitoring data exists to be able to track trends. In addition to evaluating BMP effectiveness, the local governments operate under state permit requirements that call for monitoring to meet provisions in TMDL reports for impaired waterways. The TMDL for Murrells Inlet Estuary contains such provisions, which call for specific data collection methods that cannot be achieved with volunteer monitoring. An approach must be devised to use resources

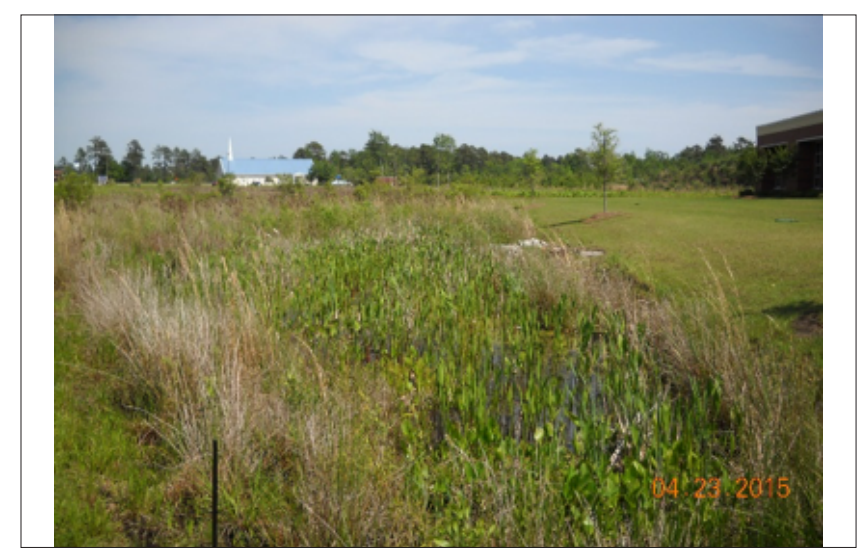

Figure 7. Constructed wetlands at recreation center in Horry County.

efficiently to best meet various monitoring needs, which may include additional volunteer and/or technical staff effort. To accomplish such an approach will require the commitment of significantly more resources than are currently allocated.

Sustaining community involvement over a ten to twenty year time period can be daunting. Early energy and enthusiasm tends to wane and implementation may fall to a few key individuals. A watershed plan implementation steering committee, composed of key stakeholders, will oversee and track plan implementation. The steering committee is intended as a vehicle for long-term community engagement. Periodic steering committee meetings are designed to keep stakeholders connected and interested. These meetings will also serve as a forum for determining project priorities as time passes. Support for the steering committee will need to come from key organizational partners, such as the

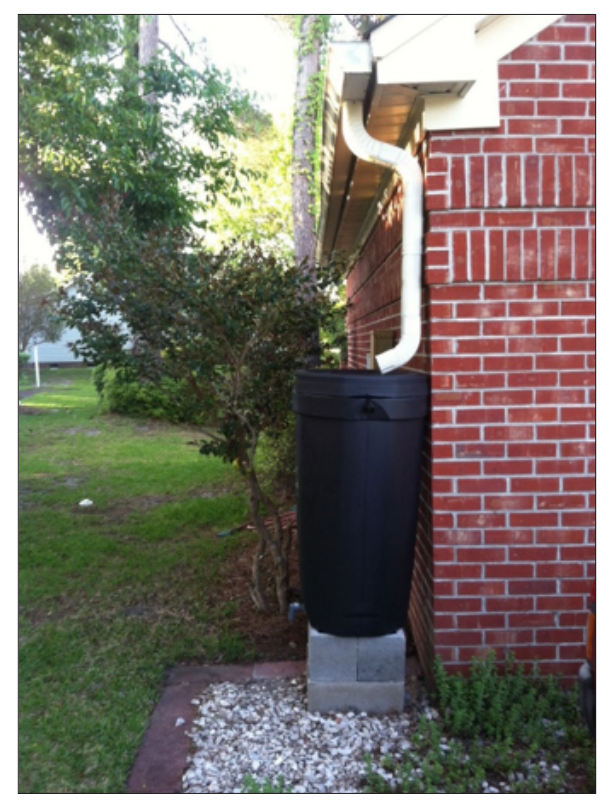

Figure 8. Rain barrel capturing roof runoff at a home in Horry County. 
local and regional governments and Murrells Inlet 2020. Sustaining this interest and energy will require ongoing coordination and communication among the partners. To meet stakeholders' expectations, water quality improvement projects will need to be consistently undertaken and water quality improvements will need to be demonstrated.

The challenge of funding plan implementation over decades is also a concern. Watershed plan implementation is a long-term endeavor that will require considerable financial and personnel commitments by SMS4s. Since there is no dedicated funding source for implementing these measures, annual budget allocations will be needed. Local funding sources may be leveraged against grant funds to boost implementation by evaluating pilot studies for BMPs or strategies that have not been tested widely, but grant funding remains scarce. This strategy is currently being used to administer a SC DHEC Section 319 implementation grant, which will allow the watershed plan steering committee to evaluate the effectiveness of BMPs before prematurely expending resources. Administering grants requires time, energy and expertise from organizational partners, so longterm commitments must be honored to achieve success.

\section{CONCLUSIONS}

Watershed planning is now widely accepted and encouraged. This case study described both the Murrells Inlet Watershed Plan development process that deeply involved the community and the implementation of its recommendations. The sometimes difficult process yielded a plan with community support that recommends measures to address the fecal coliform impairments in the estuary.

Due to the considerable investment of time and energy in the planning process, community stakeholders became committed to the plan. As a result, stakeholders also developed expectations that plan recommendations would be implemented following plan approval. Community support for the plan and its implementation is a critical part of the planning process and is largely generated through involvement in the process. It is important to recognize that it is not the outcome, but the process of active participation that engages stakeholders and engenders support for the elements of the watershed plan.

There are numerous challenges facing the stakeholders during the implementation phase. These range from geographic and space limitations to achieving voluntary adoption of low impact development techniques to mounting campaigns that aim to change behaviors. Additional complications include assessment of effectiveness of management measures, sustained community support and involvement, and dedicated funding for implementation measures. SMS4s must play a lead role in overcoming these challenges to achieve success in meeting pollution reductions in Murrells Inlet Estuary.

\section{ACKNOWLEDGEMENTS}

The Murrells Inlet Watershed Plan Steering Committee spent many hours planning, gathering information, evaluating data, and preparing and editing the document. Implementation would not be possible without their work. Of particular importance to completing the project were the co-leads for the watershed plan, Sue Sledz formerly of Murrells Inlet 2020 and Daniel Newquist of the Waccamaw Regional Council of Governments.

Technical assistance was provided by: Ray Davis and Lewis Roach of Floating Island Solutions; Rod Tyler, Britt Faucette, Jon Stewart and J.R. Stewart of Filtrexx International; Russ Britton and Steve Rodgers of EcoExpress; and Stephen Williams of The Earthworks Group.

\section{LITERATURE CITED}

Ellis, K., C. Berg, D. Caraco, S. Drescher, G. Hoffman, B. Keppler, M. LaRocco, and A. Turner, 2014. Low Impact Development in Coastal South Carolina: A Planning and Design Guide. ACE Basin and North Inlet-Winyah Bay

National Estuarine Research Reserves, 462 pp.

Faucette, B., F. Cardoso, W. Mulbry, and P. Millner, 2013. Performance of Compost Filtration Practice for Green Infrastructure Stormwater Applications. Water Environment Research, Vol. 85, No. 9.

Iasur-Kruh, L., Y. Hadar, D. Milstein, A. Gasith, and D. Minz, 2010. Microbial Population and Activity in Wetland Microcosms Constructed for Improving Treated Municipal Wastewater. Environmental Microbiology, Vol. 59, No. 4, pp. 700-709.

Karathanasis, A. D., C. L. Potter, and M. S. Coyne, 2003. Vegetation Effects on Fecal Bacteria, BOD, and Suspended Solid Removal in Constructed Wetlands Treating Domestic Wastewater. Ecological Engineering, 20:157-169.

Masters, B., 2012. The Ability of Vegetated Floating Island to Improve Water Quality in Natural and Constructed Wetlands: A Review. Water Practice and Technology, Vol. 7, No. 1.

South Carolina Department of Health and Environmental Control, 2014. Shellfish Management Area 04 - 2014 Annual Update. Shellfish Sanitation Section, Water Monitoring Assessment and Protection Division, Environmental Quality Control - Bureau of Water, Columbia, South Carolina, October 2014.

South Carolina Department of Health and Environmental Control, 2014. South Carolina Simplified Guide to Developing Watershed-based Plans. SC DHEC Report Number CR010496. Columbia, South Carolina, October 2014.

South Carolina Department of Health and Environmental Control, 2005. Total Maximum Daily Loads for Fecal Coliform in Shellfish Waters of the Murrell's Inlet Estuary, South Carolina. SC DHEC Technical Report Number 025-05. Columbia, South Carolina, July 2005. 
Tanner, C. C., and T. R. Headley, 2011. Components of Floating Emergent Macrophyte Treatment Wetlands Influencing Removal of Stormwater Pollutants.

Ecological Engineering, 37:474-486.

Treby, E. J., and M. J. Clark, 2004. Refining a Practical Approach to Participatory Decision Making: An Example from Coastal Zone Management. Coastal Management, 32:353-372.

United States Environmental Protection Agency, 2008. Handbook for Developing Watershed Plans to Protect and Restore Our Waters. US EPA Report 841-B-08002, Office of Water, Nonpoint Source Control Branch, Washington, D.C., March 2008.

Waccamaw Regional Council of Governments, 2014. 2014 Murrells Inlet Watershed Plan: A Community-based Management Plan to Address Fecal Coliform Impairments in Local Shellfish Harvesting Areas. Submitted to SC DHEC, Columbia, South Carolina, April 2014. 